\title{
Non-Buddhist Buddhism and Non-Christian Christianity in Japan
}

\author{
By HARRY THOMSEN
}

This short representation of the present state of Buddhism and Christianity does not cover the Far East, but only fapan. Neither does it cover the whole situation as it exists in Japan, but only certain aspects of it-as far as Buddhism is concerned: The Buddhist Renascence, the Buddhist Decadence, non-Buddhist Buddhism that is the so-called New Religions, Buddhism in the New Religions, and the relationship of the New Religions to Buddhism and Christianity in the near future.

A Buddhist Renascence? To the West Buddhism today in many ways represents an image of renascence, of surging expansion. Buddhist missionaries have been sent from Japan and other Buddhist countries to almost any country in the West, Buddhist delegations once a rarity are now seen all over the globe, and the number of Buddhists in the West is rising steadily, so that they at present count about 500,000 in the USA, 5,000 in England and 8,00o in Germany. Just as the influence of Zen, a very subtle influence, is seen through such vehicles as judo, tea ceremony, archery, flower arrangement, kendo, etc. This penetration of the Western world with religious and cultural mission is, however, perhaps at its highest. At least it is my impression, that the world mission - up to now some sort of prestige symbol for every Buddhist branch and sect in Japan-is entering a new phase with more emphasis on South East Asia and less emphasis on the West.

As far as fapan itself is concerned, again we meet signs of life, expansion, renascence. Bus drivers may participate in large groups in the Zen meditation of a big Kamakura monastery. Factory workers have regular retreats for meditation in the Myoshinji monastery in Kyoto. People who meet various crises in life (failure in entrance examinations, traffic accidents, illness, etc.) are to be found in most of the larger Buddhist monasteries in 
Japan. A fairly large number of "white" Buddhists study Zen throughout the country. The Buddhist temples and monasteries show their aptness to assimilate the new age by all kinds of "arbeito": a monk in Fukuoka spends most of his time by carving Disney dolls, several temples in the larger cities have converted their temple-yards into car parking-lots, and other have taken up as different jobs of "arbeito" as old people's homes, kindergartens, schools, theatres, etc. in their compounds, where earlier only the 'geta' (wooden sandals) of the monks were heard.

Buddhism has even been able to show various instances of the "ultimate proof of life": conversion of Christians into Buddhists. One interesting example is the professor from Kobe, who was a Christian but became a Buddhist and explained it himself in the following way: "I could not understand the Christian dogmas-I found Christianity un-logical-and when I heard the sound of the temple bell in the middle of the night I knew that Buddhism is where I belong."

There is no doubt, that an expansion during the latter years has taken place in lay Buddhism. A nation-wide system of Buddhist sunday schools, kindergartens, etc. is being developed. In imitation of Christianity YMBA's and YWBA's are formed. Comic series with Buddha taking the place of Superman are distributed. And every Sunday in Tokyo Union Buddhist church (not 'temple') services are held in English with hymns, responsive reading, and 'space-age sermons'.

A Buddhist Decadence? Hand in hand with the Buddhist renascence an unmistakable decadence is taking place. The majority of the Japanese people do not know the name of their Buddhist sect and profess to have no interest in it. Buddhism is called ' $h a k a$ shukyo'-graveyard religion-a religion only concerned with the dying or the dead-a not altogether wrong definition; undoubtedly the most important and time-consuming work of Buddhism in Japan is taking care of the dead, and it also furnishes most of the income for most of the temples. In contrast to the times of the patriarchs Kukai, Saikyo, Nichiren etc., when Buddhist monks were pioneers in road-building, hostpitals, etc.

Newspapers abound with articles showing the decadence of Buddhism. A thief caught in a village - who turned out to be the priest from the village 9-68438I Hartman 
temple. Zen monks playing majong or baseball in the monastery or drinking with hostesses in bars in Kobe. Electrion fraud and tax evasions at temple headquarters. Etc.

In the midst of the decadence is Buddha, who has a much less prominent place in the temples in Japan than on the continent. In Japan in most cases the prominent place is left for the founder of the particular Buddhist sect: Honen, Shinran, Nichiren, etc. Whereas Buddha is the undisputed 'king of advertisement', figuring on ash-trays, match-boxes and bath-towels. As a Buddhist leader from Siam put it "Nowhere in the world are sacred matters used so profanely as in Japan".

In the training monasteries where I00-150 monks meditated before the war, now generally only 5 or Io monks are found. And if tradition did not require the oldest son of a priest or monk to carry on, there is no doubt that it would be absolutely impossible to staff all the 72,00o Buddhist temples throughout the country. The attitude of these older sons destined to follow their fathers is well illustrated in statistics as the following, which has been taken at the elite Buddhist university for older sons in Kyoto, the heart of Buddhism, Ryukoku. The students were asked "Do you think that Buddhism can solve the problems of Japan?" 3 per cent answered 'yes', $5^{\mathrm{I}}$ per cent 'no'. To the question "Are you going to be a Buddhist priest" 54.8 per cent answered 'yes'. To the question "Have you ever thought of committing suicide?" $5^{\text {I.4 }}$ per cent answered 'yes'.

The place of Buddha, as treated above, must not be confused with typical Zen phrases about Buddha as the following by Rinzai: "The Buddha is just like all other bald monks, unhappy he who seeks enlightenment through him. Seek Buddha and you shall lose him." Or: "If you meet Buddha, kill him." Or compare with the Buddhist monk who burnt the finest Buddha statue in his monastery, because he was cold. - In these instances there is no disrespect, no profanity, on the contrary these are main dogmas of Zen, which incidentally claims to have no dogmas.

Non-Buddhist Buddhism. At this time we will leave Buddhism, apparently, and have a look at one of the most interesting religious phenomena in the history of Japan, the emergence of the so-called New Religions.

Before the Meiji era there were only three major religions in Japan 
—chronologically speaking Shinto, Buddhism and Christianity. Taoism never crossed over from China, and Confucianism never as a religion, however as a strong factor in ethics. There is also evidence that Jewism migrated to Japan, via China where Jewish settlements have been provenabout 35 Japanese words (nagar), some children's verses, some religious customs (circumcision, etc.) etc. are arguments for a Jewish presence, that long ago has ceased to be apparent. Christianity came to Japan for the first time not through Francis Xavier as many believe, but through some Nestorians from the Chinese court of Loyang (torii, Isarai ido, etc.) in the $7^{\text {th }}$ and 8 th centuries. But, as in China, the Nestorians completely disappeared - the last we hear of them was the ill-fated invasion forces of Djengis Khan in the late $13^{\text {th }}$ century, which left behind it numerous cross-marked helmets on the shore of Kyushu, where the battle took place.

From the beginning of the Meiji era, and particularly after the second World War, the New Religions mushroom onto the Japanese religious stage. At some time there were no less than about $35^{\circ}$ of them, but now only about 169 are left. Their main reasons for success were the decadence of Buddhism, regarded as something from the past by most post-war Japanese, and Shinto compromised by being attached to the ultra-nationalism-and the failure of Christianity of filling the religious vacuum, mainly by being un-Japanese. Contributing reasons were the following factors: the feeling of fellowship that the New Religions inspired into their believers, their simplicity, their magnificent centers, their claim to be able to heal diseases, and their fanatical zeal in propagation work. And perhaps more than anything else the fact that they were lay movements. Another factor is the strong leadership that is found in most of the New Religions. It seems that the Japanese people either have wanted to be leaders or to be led throughout history. The vertical 'oyako' relationship (emperor-people, teacher-student, father-children, etc.) has always been conspicuous. And the authority of the Emperor, after for some time being in the hands of McArthur, passed into the hands of the leaders of the New Religions.

A detailed description of the New Religions, however tempting it may be, will not be possible in this short presentation. Only one or two of them must be mentioned. First of all Soka Gakkai, which claims a membership of about 18 million (probably half this number is more correct) and shocked 
the world by jumping on to the political arena of Japan in 1959. It is a lay movement of the Nichiren branch of Buddhism. It has at present 20 members in the Upper House and has as its professed aim to win a majority in both houses in 20 years. Its political branch, Komeito, is expected to win $3^{0}$ seats in the Lower House in the next election and it has the balance of power between the two great parties in Tokyo. It is carrying on vigorous propaganda, 'shakufuku', also outside Japan and has 8,500 families in Brazil and 10,000 families in the USA, but has suffered some setbacks in Korea and other places. Soka Gakkai has a tight military organization with communist-type cell-elements-and is intensely nationalistic, so much so that there is more to fear in this respect from Soka Gakkai than from Shinto. Mention should probably be made of Rissho Kosei Kai, which is also a lay movement sprung from Nichiren Buddhism. Rissho Kosei Kai counts 3 million members and is the only religion besides Soka Gakkai that has been able to penetrate into the working classes. Its headquarters in Tokyo is the largest 'religious building' in the world and can hold about $5^{\circ}, 000$ people.

The New Religions are new in garments, attitude and approach, but as far as contents is concerned there is practically nothing new. Their teaching is the usual Japanese 'religious cocktail' with various old ingredients mixed in a new way, added new colours. As it has been said by a Japanese professor: "We like everything mixed, from food to religion." And Japan has truly demonstrated a tremendous ability to preserve the past-often better than their Chinese originals - and mix it adeptly with the present. The Japanese religious soil is in a constant ferment of syncretism. 'Ikasu', to 'let live' is one of the main principles in the culture of Japan.

According to present statistics there are 54 million Buddhists, 62 million Shintoists, 28 million belonging to the New Religions, and almost I million Christians. If this number is added, we arrive at a total of 145 millionand there are only close to 99 million Japanese. This sometimes puzzles the foreign observer, but if the above-mentioned fact is remembered it is easily understood: religions are regarded as more or less equal, they only represent different paths up to the summit of Fuji-san, and membership of one does not exclude membership of one or more others. (Besides, Japanese religious statistics must be taken with a grain of doubt.) 
One of the fairly new ingredients of the religious cocktail of the New Religions is-rather strikingly-Christianity. Apart from the crucifixion and resurrection of Jesus Christ, there is hardly any area of Christian dogma, thought, structure and method that has not been borrowed heavily from. In Ittoen the Lord's Prayer and the Sermon on the Mount are in the same service book together with Buddhist sutras-birthdays of Jesus and Buddha are celebrated-a Buddhist temple bell sounds at night every day, and a Christian church bell rings in the morning,--and the words of Christ are used as often by Tenko-san, the leader, as are the words of Buddha. In Odoro Shukyo (the Dancing Religion) the members have their own version of the Sermon on the Mount on a mountain top behind headquarters-the name of their holy writing is, polemically, used with the same phonetical sounds as that for the Bible in Japanese-and the leader, the 'femme formidable' Sayo Kitamura, calls herself 'the Christ of this age'. The motto on the cover leaf of the leading magazine of Seicho no $l e$ is the words: "Ye shall know the truth, and the truth shall make you free," and its leader, Taniguchi Masaharu, was recently received in interview by the Pope in Rome. In Tenrikyo the attempted suicide of the foundress, Miki Nakayama, is explained as an 'offering of redemption'. And in one of the local temples of one New Religion in Kyushu, the old Amida statue has been re-baptized 'Iesu-same', 'Jesus'. Similar instances could be added in thousands.

This imitation of Christianity is most remarkable, considering that the same Christianity from ${ }^{6} 637$ to the Meiji era was prohibited upon the penalty of death. The imitation is not always profound or correct-thus according to one religion (Seicho no Ie) "Jesus suffered in the garden of Eden" (instead of Gethsemane). But the New Religions, who seem to have a general understanding, that you cannot talk of religion in the 2oth century without mentioning Christianity, without including some parts of Christianity, seem to have an uncanny intuitive feeling of, what to take out from the Christian context and what to exclude. On the part of the New Religions, and Buddhism, there seems to be a general concensus, that survival is only possible by including Christianity in the Japanese religious cocktail. On the part of Christianity one of the most interesting questions is, whether this will immunize the Japanese to the full gospel, or it will be one step towards a Christian Japan. 
Buddhism in the New Religions. If Christianity can be said to be the new ingredient in the cocktail of the New Religions, Buddhism (and to some extent Shintoism-but in this representation only Buddhism will be treated) can be called the bedrock of the New Religions, the oldest and the main ingredient of the cocktail. If Jesus Christ can be said to be in the pantheon of the New Religions, Buddha (Gautama or Amida) is the center of the pantheon. The general atmosphere may not be typical of Buddhism, but by far most of the dogmas are taken from it.

There is the general mixture of 'jiriki' (by own power) and 'tariki' (by power outside oneself), as far as faith and salvation is concerned, as we find in Zen and Shin (Pure Land) Buddhism. But in the New Religions salvation is thought of in more material terms, and in this world: freedom from poverty, disease and war, the Kingdom on Earth, here and now. Sin is generally thought of in the same way: 'mayoi', ignorance, something that can be overcome by man himself ('Tenrikyo)-there is nothing fundamentally wrong with man. Man is or becomes Buddha-it is only a question of time and energy before he breaks through ('satori'). Other religions are regarded by Buddhism as well as the New Religions in terms of inclusiveness, not exclusiveness as in the case of Christianity-the only exception being Soka Gakkai, which follows the intolerant narrow path of its spiritual origin, Nichiren Buddhism.

There is one notable exception to the spiritual kinship between Buddhism and the New Religions. The general atmosphere of pessimism and lifenegation found in Buddhism is lacking and has been replaced with a spirit of optimism and happiness. The original cup of suffering has been diluted, and the cup of joy floweth over. This, however, has for centuries been true to some extent about Japanese Buddhism as opposed to that on the Asian continent. In Japan the monks can eat after II o'clock-they can marry, and the discipline outside the temple compound is very lax. To be sure the 'sakura' blossoms will gently fall to the ground, but the most important thing is that they will bloom again next spring. The melancholy of the vanity of everything ('shogyo mujo') is there, but is a delightful bitter-sweet sort of melancholy. In the New Religions this general atmosphere of optimism is more marked, and sometimes approaches delirious happiness and life-zest. For example in $P L$ Kyodan (also called the 'Golf Religion') there is a golf 
teeing course on the flat roof-top of all local temples, and a magnificent $3^{6}$ hole golf course at the headquarters near Osaka.

Looking toward the future. As a Danish humorist has said "It is always dangerous to prophesy,--especially about the future". Being no prophet, however, I can freely prophesy-nobody will be surprised if I am wrong.

To me it seems that the unique phenomenon, the New Religions, is in disguise a real renascence of Buddhism. That, for one thing, it forces Buddhism into accommodating and streamlining for the new age at a much more rapid pace than would otherwise have been possible, and that, for another, the New Religions themselves in reality represent Buddhism with its fantastic ability to change. It may to some extent be said that Buddhism is a religious idea in constant movement more than a religion as such-and some observers might be tempted to say that Buddhism, as represented by the New Religions, has moved so far that it has been cut off from its roots and no more is master of its development. The Buddhist will probably answer that this is exactly the main pride of Buddhism, that it always accommodates, that it thrives on syncretism and religious cocktails, that it is always in evergreen renascence, modern to all times.

While in the process of prophesying I would like to say that I think that what is happening in Japan, the mushrooming of the New Religions, in the future will be recognized as the third major religious milestone in the history of Japan, the former two being the introduction of Buddhism in the 6th century, and the emergence of popular Buddhism in the $13^{\text {th }}$ century (Nichiren, Zen, Jodo and Shin).

Regarding the future of Christianity in confrontation with Buddhism in Japan I would like to give two opinions from Buddhist friends of mine, that will show how wide a variety of opinions there are on this subject. One of them, a Zen abbot from Kyoto, said to me when I asked him about the future of Christianity in Japan: "We in Zen at least think there is something great about Christianity, only we don't think the Christians know what it is ..." The other, a Zen master in Shizuoka, whose sense of humour was not quite so devastating, said: "Zen is the most Japanese of everything in Japan. We think of the Japanese as Japanese not as prospective members. If you Christians look to Zen, and learn from us our outlook and some of our methods, the majority of the Japanese will become Christians. If you 
do not learn from us, the Japanese will be Christians for one year, maybe 5 years, but ultimately return to us." He continued: "Maybe you do not know what to learn from us. Let me tell you. When we Buddhists swallow a mouthful of tea, we swallow the whole universe-and in the Noh drama the stage of 18 square feet is cosmos itself, where the Noh actor, we, Buddha dance and sing the life of man, with the death of man as draperies in the background. We are learning from Bultmann a certain sense of history, but so far to us the history of man is from beginningless beginning through the gateless gate to endless end..." He finished: "Now let us have a cup of tea..." 